\title{
Pyrolysis and wood by-products of species from the Brazilian semi-arid region
}

\section{Pirólise e subprodutos da madeira de espécies do semiárido brasileiro}

\author{
Ananias Francisco Dias Júnior1, Carlos Rogério Andrade², Thiago de Paula Protásio ${ }^{3}$, \\ Isabel Cristina Nogueira Alves de Melo ${ }^{4}$, José Otávio Brito ${ }^{5}$ e Paulo Fernando Trugilho ${ }^{6}$
}

\section{Resumo}

Este estudo teve por objetivo analisar a madeira de dez espécies endêmicas da região do semiárido brasileiro, sobretudo quando submetida à pirólise e caracterização do extrato pirolenhoso. Na madeira foram analisados os teores de extrativos totais, lignina e cinzas, poder calorífico e a composição química elemen$\operatorname{tar}(\mathrm{C}, \mathrm{H}, \mathrm{O}, \mathrm{N}, \mathrm{S})$. Amostras foram submetidas ao processo de pirólise flash sob uma temperatura de 500 ${ }^{\circ} \mathrm{C}$ com um tempo de permanência de 5 minutos. Os rendimentos em carvão vegetal, líquido pirolenhoso e gases não condensáveis foram determinados. Os extratos de líquidos pirolenhosos foram analisados por meio de cromatografia a gás (GC/MS) com o intuito de detecção de compostos orgânicos. A madeira das espécies Mimosa tenuiflora e Poincianella pyramidalis mostraram-se as mais indicadas para uso de biomassa para energia e para a produção de carvão vegetal em função dos seus elevados teores de lignina, rendimentos em carvão e líquido pirolenhoso. Detectou-se nos extratos pirolenhosos compostos oxigenados, como ácidos carboxílicos, ésteres, éteres e cetonas, além de fenóis, guaiacóis e derivados fenólicos.

Palavras-chave: energia da biomassa; líquido pirolenhoso; cromatografia gasosa.

\begin{abstract}
The objective of this study was to analyze wood from ten species, endemic of the Brazilian semi-arid region, especially when subjected to pyrolysis and characterization of pyroligneous extract. In the wood, the total extractive, lignin and ash contents, the calorific value, and the elementary chemical composition $(\mathrm{C}, \mathrm{H}, \mathrm{O}$, $\mathrm{N}, \mathrm{S}$ ) were analyzed. Samples were subjected to the flash pyrolysis process at a temperature of $500^{\circ} \mathrm{C}$ with a residence time of 5 minutes. The yields of charcoal, pyroligneous liquid, and non-condensing gases were determined. Pyroligneous liquid extracts were analyzed through gas chromatography (GC/MS) with the objective of detecting organic compounds. The wood of the Mimosa tenuiflora and Poincianella pyramidalis species was the most suitable for using biomass for energy purposes and to produce charcoal due to its high lignin content, charcoal yields and pyroligneous liquid. Oxygenated compounds, such as carboxylic acids, esters, ethers and ketones, as well as phenols, guaiacols and phenolic derivates were detected in the pyroligneous extracts.
\end{abstract}

Keywords: biomass energy; pyroligneous liquid; gas chromatography.

\section{INTRODUCTION}

The Caatinga, predominant vegetation in the North-Eastern semi-arid region, is characterized by the occurrence of limited and endemic forest essences, whose distribution is totally restricted to the Brazilian national territory (SILVA; OREN, 1997). In addition, several animal and vegetable species have been recently described for the biome, demonstrating a very incipient zoological and botanical knowledge.

According to Oliveira et al. (2006) and Paes et al. (2012), in the Brazilian semi-arid region, the demand for energy products is on the rise, thus increasing the pressure on the native flora, aiming

\footnotetext{
${ }^{1}$ Adjunt Professor of the Department of Forest Engineering. UFES - Universidade Federal do Espírito Santo / CCAE - Center for Agricultural Sciences and Engineering. Av. Governador Lindemberg, 316 - 29550000 - Jerônimo Monteiro, ES, Brazil. ${ }^{2}$ Professor of the Department of Forest Engineering. UFG - Universidade Federal de Goiás. Jatai Campus - Rod. BR 364, Km 192, 3800 - P.O. Box: 03 - 75801615 - Jataí, GO, Brazil.

${ }^{3}$ Associate Professor of the Department of Forest Engineering. UFRA - Universidade Federal Rural da Amazônia. Parauapebas Campus - P.O. Box: 3017 - Cidade Nova - 68515000 - Parauapebas, PA, Brazil.

${ }^{4}$ Phd in Wood Science and Technology. UFLA - Universidade Federal de Lavras. P.O. Box: 3037 - 37200000 - Lavras, MG, Brazil. ${ }^{5}$ Senior Professor of the Department of Forest Sciences. USP - Universidade de São Paulo, Luiz de Queiroz College of Agriculture, Department of Forest Sciences. Avenida Pádua Dias, 11 - P.O. Box: 09 - 13418-900 - Piracicaba, SP, Brazil.

${ }^{6}$ Full Professor of the Department of Forest Sciences. UFLA - Universidade Federal de Lavras. P.O. Box: 3037 - 37200000 - Lavras, MG, Brazil.
} 
primarily the obtainment of firewood and charcoal. Despite the importance of the vegetation in the semi-arid region as an energy source, there is a great lack of information about the woody material for this purpose.

In 2006, the Northeast Plants Association (APNE) started to develop studies in the technological and social fields, for the use of forest management of the Caatinga in rural settlements in the semi-arid regions of Pernambuco. The set of actions supported by several partnerships have provided the stabilization of methodologies, achieving favorable socioeconomic results. In this context, one finds the production of charcoal that, automatically, has generated the conception of recovering pyroligneous liquid and the chemical compounds that can be extracted from it. An important part of the action comprises the development of laboratory researches aiming to obtain basic results that will support the obtainment of the mentioned products on a field scale.

In general, the action of heat on wood in the controlled presence or absence of oxygen implies in its full degradation producing charcoal, pyroligneous liquor and non-condensing gases (BRITO, 1990). According to the author, this process is also called pyrolysis or "dry distillation of wood" that, among various phenomena, is the elimination of volatile components and the concentration of carbon in the resulting charcoal. In a general way, charcoal is the solid product obtained by wood carbonization, whose characteristics depend on the techniques used to obtain it and on the raw material of origin (BRITO, 1990; BRITO; BARRICHELO, 1980).

Pyroligneous liquor, resulting from the condensation of pyrolysis gases, consists of water in its greater part ( $80 \%$ to $90 \%-\mathrm{v} / \mathrm{v})$ and a complex mixture of various components, in which over two hundred organic compounds may be present, such as acetic acid, alcohols, acetones, esters, phenols and some lignin derivatives, hydrocarbons and nitrogen compounds (ADRIANSZ et al., 2000; GUILLÉN; IBARGOITIA, 1999; GUILLÉN; MANZANOS, 2002; GUILLÉN et al., 2001; 1995; ADRIANSZ et al., 2000). This liquid features a coloration that varies from yellow to reddish brown, which may be obtained from different vegetable species (CAMPOS, 2007; MAEKAWA, 2002; SOUZA-SILVA, 2003); however, its chemical composition is differentiated as a function of the species. In addition, the temperature used in the process may also influence its composition, which may inhibit or activate, for example, bioactive components (BROWN; VAN STADEN, 1997; MU et al., 2004) and, therefore, influence final product composition.

In Japan, the pyroligneous liquid has its use characterized in pest control in applications through the soil (MIYASAKA et al., 2001), as "organic fertilizer" in rice (TSUZUKI et al., 2000), sorghum (ESECHIE et al., 1998) and sweet potato (SHIBAYAMA et al., 1998). In addition to agricultural use, pyroligneous extract also has applications in medicinal use (GUILLÉN; IBARGOITIA, 1998; GUILLÉN et al., 1995; LOO et al., 2008) and in human food and animal feed (WANG et al., 2010), since it features a characteristic aroma (barbecue), enhancing certain types of food.

In Brazil, there are references to several initiatives aiming at consolidating this practice, however, the shortage of studies on the potential of the pyroligneous has not been sufficiently explored, which would allow a wide dissemination of its use. An example of this would be the uses in the preservative treatment of woods, organic fertilizers, soil conditioners, rooting aids and organic insecticide (SCHNITZER et al., 2015). In practical terms, in addition to reducing the emission of gases to the atmosphere, the collection, separation and commercialization of the pyroligneous from the pyrolysis process can further provide the producer with additional income, besides the charcoal.

With the objective of obtaining information about the action of heat on wood and the by-products produced from it, this study had the objective of analyzing the wood from 10 species endemic of the Brazilian semi-arid region, subjected to the pyrolysis process, in particular in regards to the characterization of the pyroligneous liquid obtained.

\section{MATERIAL AND METHODS}

The wood samples were obtained from the Northeast Plants Association (APNE), from forest management areas located in rural settlements in the state of Pernambuco. To perform this study, ten tree species, described in Table 1, from the semi-arid region were selected. 
Table 1. Studied species.

Tabela 1. Espécies estudadas.

\begin{tabular}{lll}
\hline Species & Common name & Family \\
\hline Anadenanthera colubrina var. cebil (Griseb.) Altschul & Angico de caroço & Fabaceae \\
Poincianella pyramidalis (Tul.) L.P.Queiroz & Catingueira & Fabaceae \\
Cnidoscolus quercifolius Pohl & Faveleira & Fabaceae \\
Piptadenia stipulacea (Benth.) Ducke & Jurema branca & Fabaceae \\
Mimosa tenuiflora (Willd.) Poir. & Jurema preta & Fabaceae \\
Manihot carthaginensis subsp. glaziovii (Müll.Arg.) & Maniçoba & Euphorbiaceae \\
Aspidosperma pyrifolium Mart. & Pereiro & Apocynaceae \\
Platycyamus regnelli Benth. & Pereira brava & Fabaceae \\
Jatropha grossidentata Pax \& K.Hoffm & Quebra faca & Euphorbiaceae \\
Comminphora leptophloeos (Mart.) J.B.Gillett & Umburana de cambão & Burseraceae \\
\hline
\end{tabular}

The wood samples were ground and homogenized through a 40-mesh sieve and then had the total extractive content established in accordance with the TAPPI T-12 05-75 standard (TAPPI, 1975) and the klason lignin content following the TAPPI 222 05-74 (TAPPI, 1974) standard. The ash content of the wood was obtained by means of the immediate analysis in accordance with the NBR 8112 (ABNT, 1986) standard. The higher calorific value was established in an IKA C500 calorimeter in accordance with the NBR 8633 (ABNT, 1984) standard.

For the elementary chemical analysis, the samples were ground and sieved, wherein the fraction that was used was the one that passed through the 200-mesh sieve, but was caught in the 270-mesh sieve. The quantification of carbon $(\mathrm{C})$, hydrogen $(\mathrm{H})$, nitrogen $(\mathrm{N})$ and sulfur $(\mathrm{S})$, based on the dry mass of wood, were determined in a VMC universal analyzer using helium gas as drag. The 2 mg samples were accommodated in tin capsules and completely incinerated at a pressure of $70 \mathrm{KPa}$ and oxidation tube temperature of $1,200{ }^{\circ} \mathrm{C}$. The oxygen content was obtained by difference, with the aid of Equation 1.

$$
O(\%)=100-C(\%)-H(\%)-N(\%)-S(\%)-A C(\%)
$$

Where: $\mathrm{O}=$ oxygen content; $\mathrm{C}=$ carbon content; $\mathrm{H}=$ hydrogen content; $\mathrm{N}=$ nitrogen content; $\mathrm{S}=$ sulfur content; $\mathrm{TCZ}=$ ash content.

Atomic relations between N/C, $\mathrm{H} / \mathrm{C}$ and $\mathrm{O} / \mathrm{C}$ were obtained by the ratios between the elements relating to the elementary chemical analysis and, based on these, the empirical formulas were determined.

For realizing the flash pyrolysis thermal process, the wood samples, previously dried in oven set at $103 \pm 2{ }^{\circ} \mathrm{C}$, were split and ground in a Willey type mill, using $5 \pm 1 \mathrm{~g}$ of wood passed through a 40-mesh sieve. The process was conducted in a "Gray-King Setup" (GKS) pyrolysis device, containing a glass retort tube inserted into an electric heating muffle oven, in inert atmosphere saturated with nitrogen gas, at a temperature of $500{ }^{\circ} \mathrm{C}$ for a residence time of 5 minutes. Temperature control was performed through the inclusion of thermocouples in the reaction zone of the glass tube containing the wood sample. An " $U$ " tube, immersed in ice, was used to collect the condensing gases generated. Figure 1 illustrates details of the procedure used.

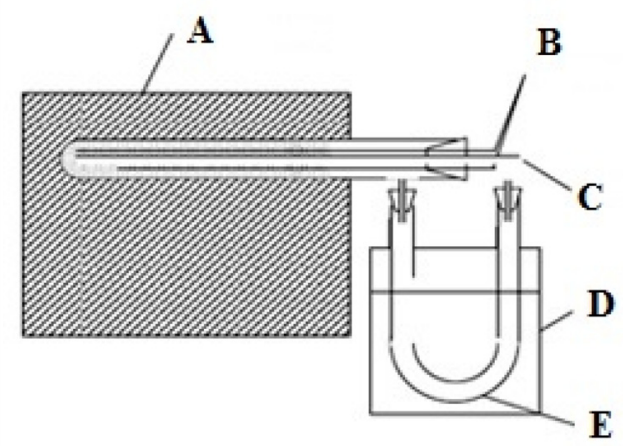

Figure 1. Pyrolysis process used - "Gray-King Setup" (GKS). Where: $A=$ muffle oven; $B=$ temperature measuring themocouple; $C=$ entry for nitrogen gas insertion; $D=$ ice container; $E=$ " $U$ " type tube for collecting pyroligneous liquid.

Figura 1. Esquema do processo de pirólise utilizado - "Gray-King Setup" (GKS). Em que: $A=$ forno mufla; $B=$ termopar para medição da temperatura; $C=$ entrada para inserção de gás nitrogênio; $D=$ recipiente para gelo; $\mathrm{E}=$ tubo tipo " $\mathrm{U}$ " para recolhimento do liquido pirolenhoso. 
Having performed the pyrolyses, the charcoal masses contained in the glass tube and the pyroligneous liquid deposited in the " $\mathrm{U}$ " type tube were measured to proceed with yield calculations. The gravimetric yields in charcoal, pyroligneous liquid and non-condensing gases were obtained with the aid of Equations 2, 3 and 4, respectively.

$$
\begin{aligned}
& R C V=\left(\frac{\mathrm{Mcv}}{\mathrm{Mm}}\right) \times 100 \\
& R L P=\left(\begin{array}{l}
\mathrm{Mlp} \\
\mathrm{Mm}
\end{array}\right) \times 100 \\
& R G N C=100-(\mathrm{RCV}+\mathrm{RLP})
\end{aligned}
$$

Where: YC $(\%)=$ yield in charcoal $(\%) ; \mathrm{Mc}=$ dry mass of charcoal; $\mathrm{Mw}=$ dry mass of wood; $\mathrm{YP}$ $(\%)=$ yield in pyroligneous liquid; Plm = pyroligneous liquid mass and YNC (\%) = yield in non-condensing gases.

Pyroligneous extracts were obtained by decanting pyroligneous liquids for a period of one hundred days and thus, they were characterized by means of analyses in gas chromatograph coupled to a Thermo Scientific mass spectrometer (GC/MC). The chromatograph uses Helium (He) as drag gas, adjusted to the initial temperature of $250{ }^{\circ} \mathrm{C}$, final temperature of $350{ }^{\circ} \mathrm{C}$, flow of $24 \mathrm{ml} \mathrm{min}^{-1}$, mass spectrometer oven temperature ranging from $40{ }^{\circ} \mathrm{C}$ to $270{ }^{\circ} \mathrm{C}$, with a heating rate of $15^{\circ} \mathrm{C} \mathrm{min}{ }^{-1}$ until the completion of the analyses. The volume of the pyroligneous liquid inserted was $1.0 \mu \mathrm{l}$.

The data obtained in this study was first submitted to the test of normality (Shapiro Wilk) and to the variance homoscedasticity test (Levene). For the variance analysis (ANAVA), a fully randomized design (DIA) with five repetitions per species and, for multiple comparison of the means, the Scott-Knott test was applied at 95\% probability. The analyses were performed with the aid of Minitab $16.1^{\circledR}$ software (MINITAB, 2010)

\section{RESULTS AND DISCUSSION}

\section{Wood characteristics}

The mean values of the chemical analysis, ash content and higher calorific value of the wood of the species analyzed are found in Table 2.

Table 2. Chemical analysis and calorific value of wood.

Tabela 2. Análise química e poder calorífico superior da madeira.

\begin{tabular}{lcccc}
\hline Species & EC (\%) & LC (\%) & AC (\%) & HCV (kcal kg-1) \\
\hline Anadenanthera colubrina & $20.68 \mathrm{a}(0.52)$ & $24.89 \mathrm{c}(1.06)$ & $1.78 \mathrm{c}(0.11)$ & $4467 \mathrm{c}(28.58)$ \\
Poincianella pyramidalis & $15.15 \mathrm{c}(0.71)$ & $25.19 \mathrm{c}(0.68)$ & $2.82 \mathrm{a}(0.29)$ & $4291 \mathrm{~d}(21.07)$ \\
Cnidoscolus quercifolius & $17.25 \mathrm{~b}(0.95)$ & $27.53 \mathrm{~b}(0.18)$ & $0.80 \mathrm{~d}(0.02)$ & $4888 \mathrm{a}(16.62)$ \\
Piptadenia stipulacea & $13.60 \mathrm{c}(0.49)$ & $24.91 \mathrm{c}(0.70)$ & $0.45 \mathrm{e}(0.01)$ & $4605 \mathrm{c}(14.91)$ \\
Mimosa tenuiflora & $23.31 \mathrm{a}(0.33)$ & $32.80 \mathrm{a}(0.60)$ & $0.92 \mathrm{~d}(0.05)$ & $4912 \mathrm{a}(19.91)$ \\
Manihot carthaginensis & $14.64 \mathrm{c}(2.04)$ & $23.68 \mathrm{c}(0.81)$ & $1.79 \mathrm{c}(0.11)$ & $4385 \mathrm{~d}(28.58)$ \\
Aspidosperma pyrifolium & $17.69 \mathrm{~b}(0.37)$ & $25.31 \mathrm{c}(0.28)$ & $0.92 \mathrm{~d}(0.02)$ & $4688 \mathrm{~b}(12.12)$ \\
Platycyamus regnelli & $12.59 \mathrm{c}(0.55)$ & $24.86 \mathrm{c}(0.26)$ & $0.32 \mathrm{~b}(0.02)$ & $4613 \mathrm{c}(14.33)$ \\
Jatropha grossidentata & $16.16 \mathrm{~b}(0.71)$ & $27.09 \mathrm{~b}(1.49)$ & $1.05 \mathrm{~d}(0.16)$ & $4752 \mathrm{~b}(12.99)$ \\
Comminphora leptophloeos & $21.25 \mathrm{a}(0.51)$ & $27.04 \mathrm{~b}(0.24)$ & $0.64 \mathrm{e}(0.01)$ & $4586 \mathrm{c}(16.29)$ \\
\hline
\end{tabular}

Where: $\mathrm{EC}=$ extractive content; $\mathrm{LC}=$ lignin content; $\mathrm{AC}=$ ash content; $\mathrm{HCV}=$ higher calorific value. Means followed by the same letter in the colu$\mathrm{mn}$ do not differ among themselves by the Scott-Knott test at $95 \%$ of probability. Values between brackets correspond to the standard mean error ( \pm ).

It is possible to observe that the Anadenanthera colubrina, Mimosa tenuiflora and Comminphora leptophloeos species presented the highest values for total extractive content in the wood $(>20 \%)$. These values can be considered quite high when compared, for example, with the average value of $5 \%$ for woods from four Eucalyptus clones analyzed by Santos et al. (2011). In contrast, for the lignin content, characteristic associated with the yield in charcoal, it is observed the greatest value for Mimosa tenuiflora. Woods of the Cnidoscolus quercifolius, Jatropha grossidentata and Comminphora leptophloeos species presented values close to $27 \%$ and the other species had mean values close to $25 \%$ for this variable. Despite the lignin content being associated with the yield in charcoal (PROTÁSIO et al., 2012), it is important to consider that it alone should not be used in an isolated manner for the 
selection of tree species aiming at the production of charcoal. Variables such as the basic wood density, dry mass productivity, anatomical wood characteristics and methodologies of the conversion process should also be considered (BRITO, 1990; DEMIRBAS, 2001).

Vale et al. (2010) studying species from the cerrado, found values between $25.16 \%$ and $32.31 \%$ for lignin content. Costa et al. (2014), upon evaluating wood of five species occurring in the same biome, found lignin content ranging from $19.88 \%$ to $26.87 \%$. In turn, Protásio et al. (2013) found lignin contents for Eucalyptus clones from $28.01 \%$ to $35.12 \%$, compatible with the species studied in this work and that are commonly used in obtaining charcoal. Based on the results reported in the literature, it is possible to highlight the Mimosa tenuiflora wood to be used in the production of charcoal.

With respect to ash content, the Piptadenia stipulacea and Comminphora leptophloeos species presented the lowest values, which the higher mean value detected was for the Poincianella pyramidalis wood. Paes et al. (2013), upon evaluating three species occurring in the Caatinga, obtained ash contents below $2.10 \%$. The authors explain that a high amount of ashes may result in damage to the equipment, in addition to the need for more frequent cleanings in the systems that use wood as energy source. In this sense, it is possible to say that the ash contents found were low and do not compromise the use of wood for energy purposes both as firewood for combustion and in the transformation process into charcoal.

According to Santos et al. (2011), the calorific value is an important property for expressing the amount of energy released after the complete combustion of the wood. The energy capacity of a given species is mainly influenced by the chemical composition of the wood, particularly by the contents of extractives and lignin (DEMIRBAS, 2001), fact observed by the greater value of the higher calorific value for the Mimosa tenuiflora species.

The high ash content in the wood is not beneficial, since, possibly, it will result in a charcoal with an elevated mineral content and it may further compromise the calorific value of the bio-reducer produced. Santos et al. (2013) obtained values of 4,442 kcal kg-1 for catingueira wood (Poincianella pyramidalis), a similar result to the one found in this study.

According to Table 3, the Mimosa tenuiflora species, in absolute terms, presented elevated mean values for nitrogen, carbon and hydrogen contents. Due to these values, the lowest mean oxygen value is detected when compared to the other analyzed species.

Table 3. Elementary chemical composition.

Tabela 3. Composição química elementar.

\begin{tabular}{llcccc}
\hline Species & $\mathbf{C ~ ( \% )}$ & $\mathbf{H ~ ( \% )}$ & $\mathbf{O}(\%)$ & $\mathbf{N ~ ( \% )}$ & $\mathbf{S ~ ( \% ) ~}$ \\
\hline Anadenanthera colubrina & 50.84 & 6.04 & 41.47 & 1.59 & 0.056 \\
Poincianella pyramidalis & 47.36 & 5.68 & 46.03 & 0.89 & 0.038 \\
Cnidoscolus quercifolius & 48.87 & 6.16 & 43.42 & 1.48 & 0.070 \\
Piptadenia stipulacea & 48.52 & 6.15 & 43.76 & 1.49 & 0.083 \\
Mimosa tenuiflora & 47.69 & 7.79 & 42.64 & 1.83 & 0.052 \\
Manihot carthaginensis & 47.36 & 5.67 & 46.14 & 1.74 & 0.094 \\
Aspidosperma pyrifolium & 48.74 & 6.04 & 43.71 & 1.46 & 0.053 \\
Platycyamus regnelli & 47.44 & 5.81 & 45.64 & 1.06 & 0.057 \\
Jatropha grossidentata & 48.49 & 5.92 & 44.13 & 1.41 & 0.049 \\
Comminphora leptophloeos & 48.22 & 5.93 & 44.52 & 1.30 & 0.032 \\
\hline Where
\end{tabular}

Where: $\mathrm{N}=$ nitrogen content; $\mathrm{C}=$ carbon content; $\mathrm{H}=$ hydrogen content; $\mathrm{S}=$ sulfur content; $\mathrm{O}=$ oxygen content.

The Manihot carthaginensis species, in addition to presenting a high value for the nitrogen content $(>1.70 \%)$, presented a higher value for sulfur content. It can be said that the amount of sulfur obtained in this study for the analyzed species does not have a negative effect on the environment and, thus, does not limit the use of wood of the species for energy purposes, such as fuel (BUFALINO et al., 2012; PROTÁSIO et al., 2013).

Furthermore, according to Demirbas (2003), the emissions of gases made up of sulfur by the combustion $\left(\mathrm{OS}_{2}\right)$ can be considered negligible when it comes to plant biomass. For energy production, it is desirable for the biomass to present low amounts of nitrogen and sulfur, since these constituents can contribute to the formation of acid rain and corrosion of the equipment used, due to the release of $\mathrm{NO}_{x}$ and $\mathrm{OS}_{\mathrm{x}}$ gases during combustion reactions (KUMAR et al., 2010; BUFALINO et al., 2012). Still in this sense, these elements contribute little to the calorific value of the fuel (HUANG et al., 2009).

Sci. For., Piracicaba, v. 46, n. 117, p. 65-75, mar. 2018

DOI: dx.doi.org/10.18671/scifor.v46n117.06 
Considering that the eucalyptus wood has been widely used for energy purposes, the results here obtained demonstrate the high potential of the native species from the Brazilian semi-arid. Protásio et al. (2013) observed, for wood from Eucalyptus clones, a mean nitrogen content of $0.10 \%$, lower than the means obtained in this study. Pereira et al. (2013) found nitrogen contents, ranging from $0.09 \%$ to $0.12 \%$ for the wood from six Eucalyptus clones with an age of 7.5 years. For Brand (2010), the elementary chemical composition (Table 3 ) forms the basis of combustion calculations and the estimate of the enthalpy of combustion of the wood, with it being essential in choosing tree species for energy use. Based on this, the most recommended species would be the ones having wood with the highest carbon and nitrogen contents in their composition.

Observing Table 4, it is possible to notice that in absolute terms, the highest $\mathrm{H} / \mathrm{C}$ ratio was for the Mimosa tenuiflora wood, whereas the highest $\mathrm{O} / \mathrm{C}$ and N/C ratios were for Manihot carthaginensis wood.

Table 4. Elementary atomic relationships of the analyzed woods.

Tabela 4. Relações atômicas elementares das madeiras analisadas.

\begin{tabular}{lcccc}
\hline Species & H/C & O/C & N/C & Empirical Formula \\
\hline Anadenanthera colubrina & 0.119 & 0.816 & 0.031 & $\mathrm{C}_{100} \mathrm{H}_{12} \mathrm{O}_{81} \mathrm{~N}_{3}$ \\
Poincianella pyramidalis & 0.123 & 0.971 & 0.019 & $\mathrm{C}_{100} \mathrm{H}_{12} \mathrm{O}_{97} \mathrm{~N}_{2}$ \\
Cnidoscolus quercifolius & 0.126 & 0.888 & 0.030 & $\mathrm{C}_{100} \mathrm{H}_{13} \mathrm{O}_{89} \mathrm{~N}_{3}$ \\
Piptadenia stipulacea & 0.127 & 0.902 & 0.031 & $\mathrm{C}_{100} \mathrm{H}_{13} \mathrm{O}_{90} \mathrm{~N}_{3}$ \\
Mimosa tenuiflora & 0.135 & 0.566 & 0.032 & $\mathrm{C}_{100} \mathrm{H}_{16} \mathrm{O}_{57} \mathrm{~N}_{3}$ \\
Manihot carthaginensis & 0.125 & 0.974 & 0.038 & $\mathrm{C}_{100} \mathrm{H}_{12} \mathrm{O}_{97} \mathrm{~N}_{4}$ \\
Aspidosperma pyrifolium & 0.124 & 0.897 & 0.030 & $\mathrm{C}_{100} \mathrm{H}_{12} \mathrm{O}_{90} \mathrm{~N}_{3}$ \\
Platycyamus regnelli & 0.122 & 0.962 & 0.022 & $\mathrm{C}_{100} \mathrm{H}_{12} \mathrm{O}_{96} \mathrm{~N}_{2}$ \\
Jatropha grossidentata & 0.122 & 0.910 & 0.029 & $\mathrm{C}_{100} \mathrm{H}_{12} \mathrm{O}_{91} \mathrm{~N}_{3}$ \\
Comminphora leptophloeos & 0.123 & 0.923 & 0.027 & $\mathrm{C}_{100} \mathrm{H}_{12} \mathrm{O}_{92} \mathrm{~N}_{3}$
\end{tabular}

High N/C ratios provide smaller quantities of released nitrogen during the combustion of wood releasing $\mathrm{CO}_{2}$. In summary, the smaller the $\mathrm{N} / \mathrm{C}$ ratio the faster will be the combustion and release of carbon dioxide (greenhouse gas) by the wood. For the carbonization process, the H/C ratio may indicate the material's degree of transformation, thus, the wood presenting the smaller ratio will have greater ease in forming charcoal resulting from the loss of hydrogen for the elimination of water (CHUN et al., 2004). According to the authors, smaller $\mathrm{O} / \mathrm{C}$ ratios indicate that the materials present low affinity with the water, resulting from the connection of oxygen to hydrogen and, therefore, the greater the oxygen content the greater will be the possibility of this connection occurring. As it is a case of energy use, the greater $\mathrm{O} / \mathrm{C}$ ratio is a negative aspect, as a function of the water that will be formed and the energy consumed for its evaporation.

\section{Wood pyrolysis}

It is observed in Table 5 that woods from the Mimosa tenuiflora, Manihot carthaginensis and Platycyamus regnelli species obtained the highest charcoal yields.

Table 5. Gravimetric yield in charcoal (YC), pyroligneous liquid (YP) and in non-condensing gases (YNC).

Tabela 5. Rendimento gravimétrico em carvão vegetal (YC), líquido pirolenhoso (YP) e em gases não condensáveis (YNC).

\begin{tabular}{lccc}
\hline Species & YC (\%) & YP (\%) & YNC (\%) \\
\hline Anadenanthera colubrina & $26.81 \mathrm{c}(2.38)$ & $26.76 \mathrm{~d}(1.66)$ & $46.42 \mathrm{~b}(0.98)$ \\
Poincianella pyramidalis & $30.01 \mathrm{~b}(2.20)$ & $36.39 \mathrm{a}(1.65)$ & $33.60 \mathrm{e}(1.01)$ \\
Cnidoscolus quercifolius & $23.56 \mathrm{~d}(1.98)$ & $34.77 \mathrm{~b}(1.95)$ & $41.67 \mathrm{c}(1.55)$ \\
Piptadenia stipulacea & $28.98 \mathrm{~b}(3.33)$ & $37.94 \mathrm{a}(2.22)$ & $33.08 \mathrm{e}(1.49)$ \\
Mimosa tenuiflora & $32.72 \mathrm{a} \mathrm{(3.42)}$ & $30.77 \mathrm{c}(2.35)$ & $36.52 \mathrm{~d}(1.78)$ \\
Manihot carthaginensis & $31.88 \mathrm{a}(1.91)$ & $32.44 \mathrm{c}(1.28)$ & $35.68 \mathrm{~d}(2.01)$ \\
Aspidosperma pyrifolium & $23.27 \mathrm{~d}(5.33)$ & $24.22 \mathrm{~d}(3.32)$ & $52.52 \mathrm{a}(0.99)$ \\
Platycyamus regnelli & $32.52 \mathrm{a}(2.37)$ & $34.87 \mathrm{~b}(1.10)$ & $32.61 \mathrm{e}(1.36)$ \\
Jatropha grossidentata & $29.39 \mathrm{~b}(4.21)$ & $34.34 \mathrm{~b}(3.20)$ & $36.27 \mathrm{~d}(1.47)$ \\
Comminphora leptophloeos & $28.81 \mathrm{~b}(4.20)$ & $33.09 \mathrm{~b}(3.49)$ & $38.10 \mathrm{c}(1.36)$ \\
\hline
\end{tabular}

Means followed by the same letter in the column do not differ among themselves by the Scott-Knott test at $95 \%$ of probability. Values between brackets correspond to the standard mean error $( \pm)$. 
For yield in pyroligneous liquid, Poincianella pyramidalis and Piptadenia stipulacea presented themselves as potential species for obtaining this product. In consequence of these results, these species, together with Platycyamus regnelli, presented the lowest mean yield values in non-condensing gases.

The chemical composition of the extractives, as well as their thermal stability, can positively affect the yield of charcoal (PROTÁSIO et al., 2012). According to Costa et al. (2014), the quality of the lignin represented by the siringil/guaiacil (S/G) ratio must as small as possible to achieve good charcoal yields, since lignin will present a more condensed and stable structure. This may justify the fact that some species with high lignin contents are not corresponded by high charcoal yields, unlike Mimosa tenuiflora wood that obtained, in this study, higher lignin values and charcoal yields. The presence of extractives with low resistance to thermal degradation in the wood is also a fact that may explain the occurrence of such fact (DEMIRBAS, 2001). This result was also observed by Costa et al. (2014), who worked with species from the Cerrado of the state of Minas Gerais.

The charcoal yield values obtained by Costa et al. (2014) remained from 30.88\% to $34.39 \%$. These values are consistent with those obtained for the Mimosa tenuiflora, Poincianella pyramidalis, Manihot carthaginensis and Platycyamus regnelli species and are lower than those obtained by Oliveira et al. (2006) for wood of the Mimosa tenuiflora species, ranging from 37.82\% to $41.06 \%$ (yield in charcoal) and from $30.56 \%$ to $34.31 \%$ (yield in pyroligneous liquid). Such differences may be associated with different variables of the pyrolysis process applied on the materials.

The yield in charcoal, pyroligneous liquid and non-condensing gases is affected by the carbonization conditions and by the chemical and physical characteristics of the wood (OLIVEIRA et al., 2006; VALE et al., 2010).

The results of the chromatography analyses of the wood's pyroligneous extracts are shown in Table 6, which summarizes the peaks of the chemical components detected (Figure 2).

Table 6. Chemical compounds detected in the pyroligneous extract.

Tabela 6. Compostos químicos detectados no extrato pirolenhoso.

\begin{tabular}{|c|c|c|c|c|c|c|c|c|c|c|}
\hline \multirow{2}{*}{ Compound Identified } & \multicolumn{10}{|c|}{ Species } \\
\hline & AC & PP & $\mathbf{C Q}$ & PS & MT & MC & AP & PR & JM & CL \\
\hline Methanol (1) & $x$ & $x$ & $\mathrm{x}$ & $x$ & $x$ & $\mathrm{x}$ & $x$ & $\mathrm{x}$ & $x$ & $x$ \\
\hline Methyl acetate ${ }^{(2)}$ & $x$ & $x$ & $x$ & $x$ & $x$ & $x$ & $x$ & $x$ & $x$ & $x$ \\
\hline 2,3-butanedione ${ }^{(3)}$ & $x$ & $x$ & $x$ & $x$ & $x$ & $x$ & $x$ & $x$ & $x$ & $x$ \\
\hline Acetic acid ${ }^{(4)}$ & $x$ & $x$ & $x$ & $x$ & $x$ & $x$ & $x$ & $x$ & $x$ & $x$ \\
\hline 1-Hydroxy-2-propanone ${ }^{(5)}$ & $x$ & $x$ & $x$ & $x$ & $x$ & $x$ & $x$ & $x$ & $x$ & $x$ \\
\hline 1-hydroxy-2-butanone ${ }^{(6)}$ & $x$ & $x$ & $x$ & $x$ & $x$ & $x$ & $x$ & $x$ & $x$ & $x$ \\
\hline 3-furaldehyde ${ }^{(7)}$ & $x$ & $x$ & $x$ & $x$ & $x$ & $x$ & $x$ & $x$ & $x$ & $x$ \\
\hline 2-furametol ${ }^{(8)}$ & $x$ & $x$ & $x$ & $x$ & $x$ & $x$ & $x$ & $x$ & $x$ & $x$ \\
\hline 1-(2-furanil)etanone ${ }^{(9)}$ & $x$ & $x$ & $x$ & $x$ & $x$ & $x$ & $x$ & $x$ & $x$ & $x$ \\
\hline 5-methyl-2-furaldehyde ${ }^{(10)}$ & $x$ & $x$ & $x$ & $x$ & $x$ & $x$ & $x$ & $x$ & $x$ & $x$ \\
\hline Phenol (11) & $x$ & $x$ & $x$ & $x$ & $x$ & $x$ & $x$ & $x$ & $x$ & $x$ \\
\hline Corilon ${ }^{(12)}$ & $x$ & $x$ & $x$ & $x$ & $x$ & $x$ & $x$ & $x$ & $x$ & $x$ \\
\hline 3-metilphenol (13) & $x$ & $x$ & $x$ & $x$ & $x$ & $x$ & $x$ & $x$ & $x$ & $x$ \\
\hline 4-metilphenol ${ }^{(14)}$ & $x$ & $x$ & $x$ & $x$ & $x$ & $x$ & $x$ & $x$ & $x$ & $x$ \\
\hline 4-metoxiphenol ${ }^{(15)}$ & $x$ & $x$ & $x$ & $x$ & $x$ & $x$ & $x$ & $x$ & $x$ & $x$ \\
\hline 2-metoxi-4-metilphenol (16) & $x$ & $x$ & $x$ & $x$ & $x$ & $x$ & na & na & $x$ & $x$ \\
\hline 4-ethyl-2-methoxyphenol (17) & na & na & $x$ & $x$ & $x$ & $x$ & $x$ & $x$ & $x$ & $x$ \\
\hline 2.6-dimetoxyphenol ${ }^{(18)}$ & na & $x$ & $x$ & na & $x$ & $x$ & $x$ & $x$ & na & $x$ \\
\hline 1,2,4-trimetoxybenzene ${ }^{(19)}$ & $x$ & na & $x$ & na & na & na & $x$ & $x$ & na & $x$ \\
\hline 5-tert-Butylpyrogallol ${ }^{(20)}$ & $x$ & $\mathrm{x}$ & nd & $\mathrm{x}$ & $\mathrm{x}$ & nd & nd & $x$ & $x$ & nd \\
\hline
\end{tabular}

The represented chromatogram is related to one of the studied species (Mimosa tenuiflora), identifying only the more representative components in terms of percentage concentration. However, it should be noted that some substances of higher molecular weight were not detected in the woods of the studied species. Such fact may be related to the fact that, for a given species, the temperature of pyrolysis is responsible for the molecular breakage of organic compounds.

Sci. For., Piracicaba, v. 46, n. 117, p. 65-75, mar. 2018

DOI: dx.doi.org/10.18671/scifor.v46n117.06 


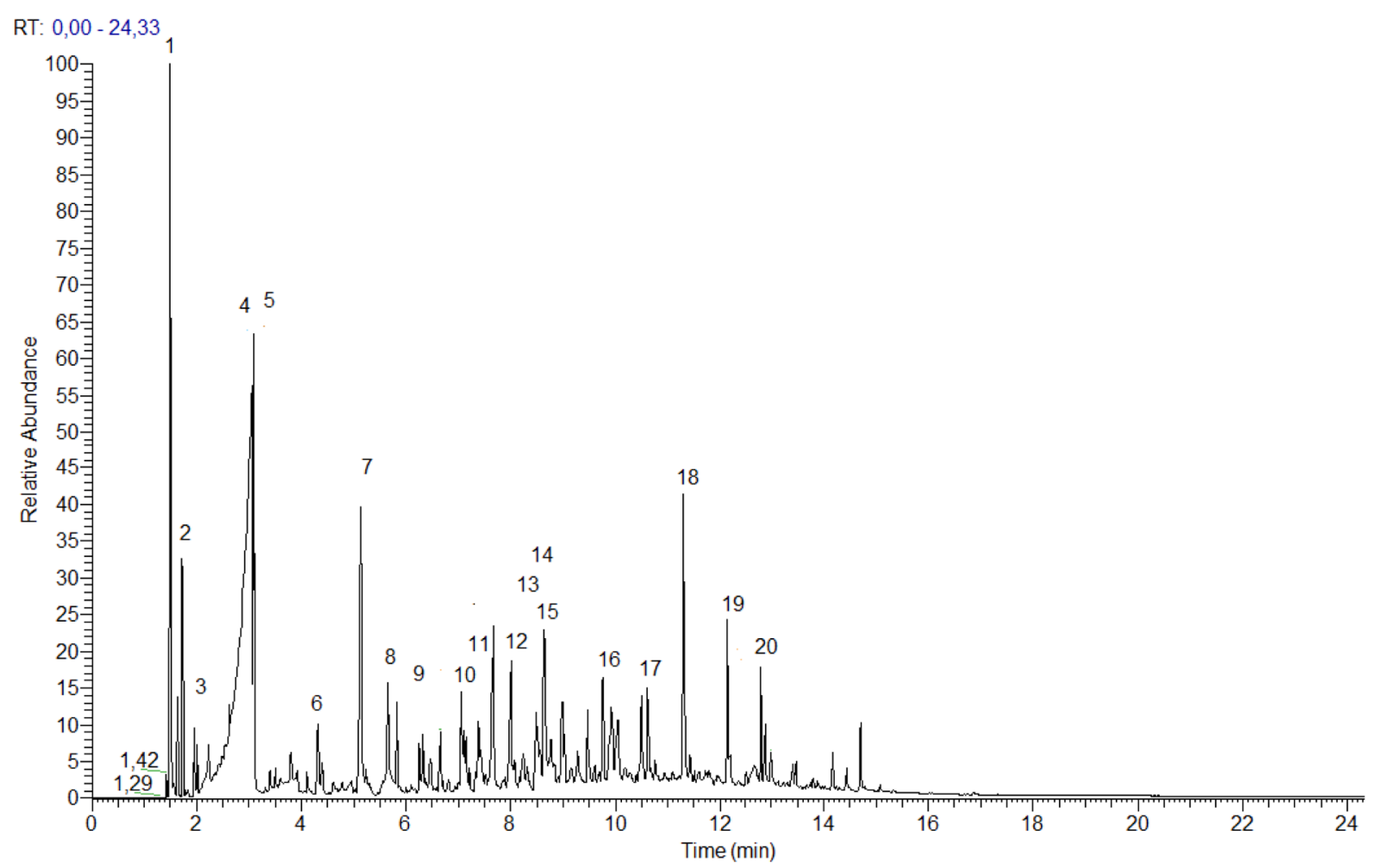

Figure 2. Cromatograma do extrato pirolenhoso da madeira de Mimosa tenuiflora.

Figura 2. Chromatogram of the pyroligneous extract of the Mimosa tenuiflora wood.

The pyroligneous extracts composition may vary according to the species of the carbonized wood, temperature and pyrolysis duration. According to Almeida (1982), the largest part of the pyroligneous extract consists of water and the remainder of organic compounds, whereas acetic acid is the predominant compound.

The antifungal properties of the pyroligneous liquid (acids, aldehydes, benzene derivatives) in the treatment of wood (MOURANT et al., 2008) and in the partial replacement of phenol in resins (phenol derivatives) for the manufacture of panels are mentioned, achieving promising results regarding mechanical properties (AMEN-CHEN et al., 2002; CHAN et al., 2002; MOURANT et al., 2008). The pyroligneous diluted in water at a concentration from 0.33 to $2 \%$ (v/v), when applied to the soil improves its physical, chemical and biological properties, providing an increase of beneficial micro-organisms and easing nutrient absorption from the soil solution by the plants. However, its use is not recommended in agriculture without first going through an initial stage of purification (extraction of soluble tar). This is achievable by means of an industrial process with vacuum distillation or in an artisan way via settling (MIYASAKA et al., 1999).

The results obtained for the wood of the analyzed species indicate the possibility of using the products obtained by pyrolysis, as well as they open the perspectives of the potential yet to be explored, with emphasis given to the production of biomass for energy generation and the use of wood pyrolysis by-products of the species from the Brazilian semi-arid.

\section{CONCLUSIONS}

The wood of the Mimosa tenuiflora and Poincianella pyramidalis species was the most suitable for energy use (combustion and pyrolysis).

With respect to the chemical composition of the pyroligneous extracts, in qualitative terms, the analyzed species did not display different behaviors. The analyses demonstrated the presence of oxygenated compounds, such as carboxylic acids, esters, ethers and ketones, as well as phenol, guaiacol and phenolic derivatives.

Future studies are suggested with the objective of identifying better potential uses of the pyroligneous liquid based on its chemical composition. 


\section{ACKNOWLEDGEMENTS}

We thank the Northeast Plants Association for providing study material, the Coordination for the Improvement of Higher Education Personnel (CAPES), the Forest Science and Research Institute (IPEF) and the National Council for Scientific and Technological Development (CNPq/142075/20167) for the provision of scholarships.

\section{REFERENCES}

ABNT - ASSOCIAÇÃO BRASILEIRA DE NORMAS TÉCNICAS. NBR - 8112 - Carvão Vegetal - Análise imediata. Rio de Janeiro, 1986. 5 p.

ABNT - ASSOCIAÇÃO BRASILEIRA DE NORMAS TÉCNICAS. NBR 8633: carvão vegetal: determinação do poder calorífico: método de ensaio. Rio de Janeiro, 1984. 12 p.

ADRIANSZ, T. D.; RUMMEY, J. M.; BENNETT, I. J. Solid phase extraction and subsequent identification by gás-chromatography-mass spectrometry of a germination cue present in smoke water. Analytical Letters, v. 33, n. 13, p. 2793- 2804, 2000.

ALMEIDA, M. R. Recuperação de alcatrão em fornos de alvenaria. Produção e Utilização de carvão vegetal. Belo Horizonte: Fundação Centro Tecnológica de Minas Gerais - CETEC, 1982. 393 p.

AMEN-CHEN, C.; RIEDL, B.; WANG, X. M.; ROY, C. Softwood bark pyrolysis oil-PF resols. Part 1. Resin synthesis and OSB mechanical properties. Holzforschung, v. 56 p. 167-175, 2002.

BRITO, J. O. Princípios de produção e utilização de carvão vegetal de madeira. Piracicaba: IPEF, 1990. 19 p. (Documentos Florestais, 9)

BRITO, J. O.; BARRICHELO, L. E. G. Correlações entre características físicas e químicas da madeira e a produção de carvão vegetal: 2. Densidade da madeira x densidade do carvão. Revista IPEF, n. 20, p.101-113, 1980.

BROWN, N. A. C; VAN STADEN, J. Smoke as a germination cue: a review. Plant Growth Regulation, v. 22, n. 2, p. 115-124, 1997.

BUFALINO, L.; PROTÁSIO, T. P.; COUTO, A. M.; NASSUR, O. A. C.; SÁ, V. A. TRUGILHO, P. F.; MENDES, L. M. Caracterização química e energética para aproveitamento da madeira de costaneira e desbaste de cedro australiano. Pesquisa Florestal Brasileira, Colombo, v. 32, n. 70, p.129-137, 2012.

CAMPOS, A. D. Técnicas para Produção de Extrato Pirolenhoso para Uso Agricola. Pelotas: Embrapa Clima Temperado, 2007. (Circular Técnica, 65)

CHAN, F.; RIEDL, B.; WANG X. M.; LU, X.; AMEN-CHEN C.; ROY, C. Performance of pyrolysis oil-based wood adhesives in OSB. Forest Products Journal. v. 52, n. 4, p. 31-38, 2002.

COSTA, T. G.; BIANCHI, M. L.; PROTÁSIO, T. P.; TRUGILHO, P. F.; PEREIRA, A. J.; Qualidade da madeira de cinco espécies de ocorrência no cerrado para produção de carvão vegetal. Cerne, Lavras, v. 20, n. 1, p. 37-46, 2014.

DEMIRBAS, A. Relationships between lignin contents and fixed carbon contents of biomass samples. Energy Conversion and Management, v. 44, n. 9, p.1481-1486, 2003.

DEMIRBAS, A. Biomass resource facilities biomass conversion processing for fuels and chemicals. Energy Conversion Management, v. 42, n. 11, p.1357-1378, 2001.

Sci. For., Piracicaba, v. 46, n. 117, p. 65-75, mar. 2018

DOI: dx.doi.org/10.18671/scifor.v46n117.06 
Dias Junior et al. - Pyrolysis and wood by-products of species from the Brazilian semi-arid region

ESECHIE, H. A.; DHALIWAL, G. S.; ARORA, R.; RANDHAWA, N. S.; DHAWAN, A. K. Assessment of pyroligneous liquid as a potential organic fertilizer. In: ECOLOGICAL AGRICULTURE AND SUSTAINABLE DEVELOPMENT, 1997, Chandigarh, India. Proceedings... Chandigarh: Center for Research in Rural and Industrial Development, 1998. v.1, p. 591-595.

GUILLÉN, M. D.; IBARGOITIA, M. L. GC/MS analysis of lignin monomers, dimers and trimers in liquid smoke flavourings. Journal of the Science of Food and Agriculture, v. 79, n. 13, p. 1889-1903, 1999.

GUILLÉN, M. D.; IBARGOITIA M. L. New components with potential antioxidant and organoleptic properties, detected for the first time liquid smoke flavoring preparations. Journal of Agricultural and Food Chemistry, v. 46, n. 4, p.1276-1285, 1998.

GUILLÉN, M. D.; MANZANOS, M. J. Study of the volatile composition of an aqueous oak smoke preparation. Food Chemistry, v. 79, n. 3, p. 283-292, 2002.

GUILLÉN, M. D.; MANZANOS, M. J.; IBARGOITIA, M. L. Carbohydrate and nitrogenated compounds in liquid smoke flavourings. Journal of Agricultural and Food Chemistry, v. 49, n. 5, p. 2395-2403, 2001.

GUILLÉN, M. D.; MANZANOS, M. J.; ZABALA, L. Study of a commercial liquid smoke flavoring by means of Gas Chromatography/Mass spectrometry and fourier Transform Infrared Spectroscopy. Journal of Agricultural and Food Chemistry, v. 43, n. 2, p. 463-468, 1995.

KUMAR, R.; PANDEY, K. K.; CHANDRASHEKAR, N.; MOHAN, S. Effect of tree-age on calorific value and other fuel properties of Eucalyptus hybrid. Journal of Forestry Research, v. 21, n. 4, p. 514- 516, 2010

LOO A. Y.; JAIN, K. A., DARAH, I. B. Antioxidant activity of compounds isolated from the pyroligneous acid Rhizophora apiculata. Food Chemistry, n. 107, p. 1151-1160, 2008.

MAEKAWA, K. Curso sobre produção de carvão, extrato pirolenhoso e seu uso na agricultura. São Paulo: APAN (Associação dos Produtores de Agricultura Natural), 2002.

MINITAB, Inc. Minitab statistical software ${ }^{\mathrm{TM}}$, Release 16.0, Copyright ${ }^{\bullet}, 2010$.

MIYASAKA, S.; OHKAWARA, T.; KUNIO, N. Derivados de carvão vegetal, extrato pirolenhoso e fino de carvão na agricultura natural. São Paulo: APAN (Associação dos Produtores de Agricultura Natural), 2001.

MIYASAKA, S.; OHKAWRA, T.; UTSUMI, B. Boletim Agro - ecológico: o ponto de encontro da Agroecologia, São Paulo, n. 14, p.17, 1999.

MOURANT, D.; YANG, D.Q.; RIEDL, B.; ROY, C. Mechanical properties of wood treated with PF-pyrolytic oil resins. Holz Roh Werkst, v. 66, p. 163-171, 2008.

MU, J.; UEHARA, T.; FURUNO, T. Effect of bamboo vinegar on regulation of germination and radicle growth of seed plants II: composition of moso bamboo vinegar at different collection temperature and its effects. Journal of Wood Science, Amsterdam, n. 5, v. 50, p. 470-476, 2004.

OliVEIRA, E.; VITAL, B. R.; PIMENTA, A. S.; DELlA LUCIA, R. M.; LADEIRA, A. M. M.; CARNEIRO, A. C. O. Estrutura anatômica da madeira e qualidade do carvão de Mimosa tenuiflora (Willd.) Poir. Revista Árvore, Viçosa, v. 30, n. 2, p. 311-318, 2006.

PAES, J. B.; LIMA, C. R.; OLIVEIRA, E.; SANTOS, H. C. M. Rendimento e caracterização do carvão vegetal de três Espécies de ocorrência no semiárido brasileiro. Ciência da Madeira, Pelotas, v. 3, n. 1, p. 01-10, 2012.

PAES, J. B.; LIMA, C. R.; OLIVEIRA, E.; MEDEIROS NETO, P. N. Características físico-química, energética e dimensões das fibras de três espécies florestais do semiárido brasileiro. Floresta e Ambiente, Seropédica, v. 20, n. 4, p. 550-555, 2013. 
PEREIRA, B. L. C.; CARNEIRO, A. C. O.; CARVAlHO, A. M. M. L.; COlODETTE, J. L. OliVEIRA, A. C.; FONTES, M. P. F. Influence of chemical composition of Eucalyptus wood on gravimetric yield and charcoal properties. BioResources, v. 8, n. 3, p. 4574-4592, 2013.

PROTÁSIO, T. P.; COUTO, A. M.; REIS, A. A.; TRUGIlHO, P. F.; GODINHO, T. P. Potencial siderúrgico e energético do carvão vegetal de clones de Eucalyptus spp. aos 42 meses de idade. Pesquisa Florestal Brasileira, Colombo, v. 33, n. 74, p. 137-149, 2013.

PROTÁSIO, T. P.; TRUGIlHO, P. F.; NEVES, T. A.; VIEIRA, C. M. M. Análise de correlação canônica entre características da madeira e do carvão vegetal de Eucalyptus. Scientia Forestalis, Piracicaba, v. 40, n. 95, p. 317-326, 2012.

SANTOS, R. C.; CARNEIRO, A. C. O.; PIMENTA, A. S.; CASTRO, R. V. O.; MARINHO, I. V; TRUGILHO, P. F. Potencial energético da madeira de espécies oriundas de plano de manejo florestal no Estado do Rio Grande do Norte. Ciência Florestal, Santa Maria, v. 23, n. 2, p. 491 - 502, 2013.

SANTOS, R. C.; CARNEIRO, A. C. O.; CASTRO, A. F. M.; CASTRO, R.V. O.; BIANCHE, J. J.; SOUZA, M. M. Correlações entre os parâmetros de qualidade da madeira e do carvão vegetal de clones de eucalipto. Scientia Forestalis, Piracicaba, v. 39, n. 90, p. 221 - 230, 2011. .

SCHNITZER, J. A.; SU, M. J.; VENTURA, M. U.; FARIA, R. T. Doses de extrato pirolenhoso no cultivo de orquídea. Revista Ceres, Lavras, v. 62, n. 1, p. 101 - 106, 2015.

SHIBAYAMA, H.; MASHIMA, K.; MITSUTOMI, M.; ARIMA, S. Effects of application of pyroligneous acid solution produced in Karatsu city on growth and free sugar contents of storage roots of sweet potatoes. Marine and Higland Bioscience Center Report, v. 7, p. 15-23, 1998.

SILVA, J. M. C.; OREN, D. C. Geographic variation and conservation of the Moustached Woodcreeper (Xiphocolaptes falcirostris), na endemic and threatened species of northeastern Brazil. Bird Conservation International, Cambridge, v. 7, n. 3, p.263-274, 1997.

SOUZA-SILVA, A. Efeito do extrato Pirolenhoso sobre Atta sexdens rubropilosa Forel, 1908 (Hymenoptera: Formicidae), Syntermes molestus (Burmeister, 1983) (Isoptera: Termitidae) e mudas de eucalipto. 2003. 68 p. Dissertação (Mestrado em Agronomia) - Universidade Federal de Lavras, Lavras, 2003.

TAPPI - TECHNICAL ASSOCIATION OF PULP AND PAPER. TAPPI 12 05-75 - Industry lignin in wood. Norcross, 1975.

TAPPI - TECHNICAL ASSOCIATION OF PULP AND PAPER. TAPPI 222 05-74 - Industry preparation of wood for chemical analysis (Including procedures for removal of extractives an determination of moisture content). Norcross, 1974.

TSUZUKI, E.; MORIMITSU, T.; MATSUI, T.; Effects of chemical compounds in pyroligneous acid on root rice plant. Japan Journal Crop Science, v. 66, n. 4, p. 15-16, 2000.

VALE, A. T.; DIAS, I. S.; SANTANA, M. A. E. Relações entre propriedades químicas, físicas e energéticas da madeira de cinco espécies de cerrado. Ciência Florestal, Santa Maria, v.20, n.1, p. 137-145, 2010.

WANG, Z.; LIN, W.; SONG, W.; YAO, J. Preliminary investigation on concentrating of acetol from wood vinegar. Energy Conversion and Management, Oxford, v. 51, n. 2, p. 346-349, 2010.

Received on $10 / 24 / 2016$

Accepted on 08/09/2017

Sci. For., Piracicaba, v. 46, n. 117, p. 65-75, mar. 2018

DOI: dx.doi.org/10.18671/scifor.v46n117.06 
